\title{
Research on Vocational English Sub-Level and Sub-Module Strategies at Computer Age
}

\author{
Min Cheng ${ }^{1}$ \\ ${ }^{1}$ Jiangxi Youth Vocational College, Nanchang, Jiangxi, 330045
}

KEYWORDS: Computer Age, Vocational English, Sub-Level, Sub-Module

\begin{abstract}
With the continuous development of new curriculum reform, quality education began popular. As an important part of English teaching vocational school teaching, to improve students' language proficiency of great significance. In the context of a network of information technology continues to progress, English teaching has also entered into the computer age, which would provide the preconditions for the implementation of the sub-level English and vocational teaching strategies module. Therefore, English teachers in vocational schools need to fully study English learning situation of students taking different levels of targeted sub-modules and teaching strategies to effectively stimulate students' enthusiasm for learning English, and thus enhance their English level of practical application.
\end{abstract}

\section{Introduction}

With the implementation of vocational school enrollment policies, so that the number of vocational students began to increase, but basic English and English proficiency among vocational students there is still a reality gap, which will affect the actual vocational English classroom teaching efficiency. If teachers or in accordance with the conventional teaching strategies to implement English teaching, it would be difficult to achieve the desired results. Based on this case, the hierarchical teaching strategies and sub-modules will be born out [1]. This teaching strategy fully into account the differences in English proficiency among students, the effective implementation of the concept of quality education individualized, so that every student will be able to find their own learning objectives, so as to improve their English teaching efficiency has laid a good foundation .

\section{The Situation of Vocational English Sub-Level Teaching}

The arrival of the computer age, innovative and effective means of vocational English teaching, English teaching content have so diverse presentation forms, which will implement hierarchical teaching laid the basis in reality. Most vocational schools teaching in English, are beginning to try to implement different levels of teaching, different levels of teaching is based on well-studied students 'individual differences, combined with the students' actual English proficiency level to divide the good teaching, and then implement targeted English teaching, so as to achieve the individualized requirements of quality education so that students can get more space for development [2]. Sub-level teaching effectively integration students the requirements for all students, from the students' actual English proficiency of departure for the students to develop learning objectives in line with their own development. Most students can make through their own 
efforts to achieve this goal, get a good experience success, and thus establish confidence and interest in learning English.

\section{Sub-Level and Sub-Module Teaching Strategies of Vocational English}

Advances in science and technology information network, making the arrival of the computer era, many of the gradual integration of information technology and English teaching together, for students to create a variety of learning paths for different levels of English teaching strategies and the implementation of sub-module provides the premise of Higher condition. The new curriculum reform requires English teaching to achieve the transition to knowledge of teaching ability teaching, the use of a variety of teaching methods to implement individualized, specific safeguard students' dominant position in the teaching process. Based on this reality requires, vocational English teachers will need to effectively combine English professional features to improve students' English learning ability [3]. Hierarchical teaching strategies and sub-module fully into account the actual level of English with the individual differences of students, mainly students stratified two-stage embodiment, the first is based on the student's level of English test results are to be arranged in the same or similar professions class, AB Construction of two levels of hierarchical teaching. Followed by a second based on the English placement test scores of students in the first semester, the same or a similar profession, poor English student test scores grouped together, continue to learn the basics of English with some basic English skills. Other students who passed the exam will be able to choose the hobby and professional characteristics of a higher stage of learning English according to their own interests, like CET, majors or business English and so on.

Under the background of computer-based English teaching vocational school infrastructure has been significantly improved, showing a positive trend in information technology and the integration of teaching English. Vocational English when enrich students' basic knowledge of English and students of English language ability, should pay attention to the use of multimedia information technology to build English communication scenarios, so that students in the actual teaching can continue to improve their English communication skills. In order to make students 'knowledge of English with the English practice of organic combine vocational schools can conduct additional English proficiency exam, mainly on the students' oral English communication and English skills for evaluation, so that students can develop a good sense of English language [4]. Teacher Score module is to study all vocational English teachers divided into five groups, from the English writing, translation, reading, vocabulary, grammar and listening to the students five modules implement targeted training to enable students to gradually learn to master English the techniques and methods. Responsible team of teachers of each module requires in-depth study of teaching characteristics and teaching methods of the module, while the production of the corresponding courseware in multimedia information technology environment to share and exchange with other teams of teachers, continuous improvement and improve the teaching mode, this sub-module teaching and research to make teachers more targeted.

English hierarchical sub-module and application of the results of vocational teaching strategies required after test after students at different levels and sub-modules were tested in practice teaching, vocational schools can use information technology to build a variety of English Test for dialogue communicative situation, English situation, and we will combine the students 'English language test scores, a comprehensive analysis of the students' English proficiency. To make the students learn basic knowledge of English can effectively extend a vocational school English teachers team can also organize a variety of extra-curricular activities to enhance students' English comprehensive quality [5]. For example, you can guide students to participate in school activities association 
English, English teaching in members of the Association on a regular basis, organization and implementation of the English speech contest and so on. These colorful campus activities, not only the students' English learning outcomes can be tested and developed in the specific practice, you can also expand the horizons of students in English, students good interest in learning English, so as to enhance the English proficiency of students lay a good foundation.

Proven, based on the implementation of the next computer background level English teaching strategies and sub-module vocational education, we cannot fully understand the students' actual English level facilitate vocational English teachers to carry out targeted classroom instruction. However, teachers in particular teaching process also some considerations need to be clear, first, to make English teaching in line with the students' actual English level, the effective implementation of the concept of individualized education, for different levels of students, they need to develop in line with the specific circumstances of this level learning objectives, so that they can through their own efforts to succeed. The second is to strengthen inter-school exchanges, changing the concept of teachers and improve the teaching of English teachers. Module Teaching requires teachers teaching team are responsible for each module, in order to enrich teachers' teaching experience, you need to organize vocational schools to learn from each other, watch lectures teaching activities, at the same time, the need to keep up with other schools for teaching exchanges, better enhance the teaching ability of teachers. Finally, a clear responsibility determines the appropriate incentives. Compared with the previous English teaching, this teaching model will undoubtedly require teachers to spend more time with energy, which requires teachers have a strong sense of responsibility and vocational schools also need to launch the appropriate incentives, so as to continuously stimulate English teachers' active participation and initiative to carry out teaching and research and teaching.

\section{Conclusion}

All in all, the arrival of the computer age, English hierarchical sub-modules and implementation of vocational teaching strategies laid a good foundation. Vocational English teachers needed in the implementation of different levels and sub-module teaching, the students continue to study the actual learning, according to the teaching requirements and the specific circumstances of the students to adjust teaching strategies to better improve students' English language proficiency .

\section{REFERENCE:}

[1] Song Juxiang. Higher Levels of English teaching [J]. Science and Technology Information (academic), 2012,15: 145-146.

[2] Ding Xiaoli, Zhang Yamei. Exploration and Practice of Vocational level English Teaching [J]. Shandong Youth Administrative Cadres College, 2013,06: 114-116.

[3] Lin Lin, Ren Baoling, Chen Zhixin. Teaching Levels Higher English [J]. students (new educational concept), 2013,12: 66.

[4] Xu Xujuan. Higher Vocational Graded English and Module Teaching [J]. Education and Vocation, 2011,14: 119-120.

[5] Liang Kun, Huang Fan. using the Graded English Teaching in Higher Vocational College [J]. Popular Literature, 2013,20: 226. 